\title{
EX-ANTE DEFERENCE AND REPARATIONS, THE CASE STUDIES OF COLOMBIA AND MEXICO
}

\author{
Adriana Garcia Garcia ${ }^{1}$ \\ Centro de Investigación y Docencia Económicas (CIDE), Mexico
}

\begin{abstract}
Usually analyses of deference consider courts' review of past agency action. Governments interpret in a specific manner a norm or regulation and the judge decides the lawfulness of that interpretation after the fact. However, judges analyze governments' future decisions as well, for example in granting reparations for human rights violations. Such decisions generally engage in an analysis of future actions that the government should perform in order to redeem victims and guarantee the violation will not recur. The underpinning principle of judicial deference is that a court should not attempt to second guess or substitute its judgment for the judgment of another decision maker, nor should it opine on the wisdom of a policy or law. With respect to human rights violations, a more deferential approach might let the government determine what measures it will take by way of reparations and prevention of recurrence, while a non-deferential approach would spell out such measures in detail. Examining cases in Colombia and Mexico issued during the past 10 years, in this paper I argue that domestic courts have been granting reparations in a less deferential manner over time. This trend is very clear when analyzing non-repetition measures granted in these countries which include attempts to oblige governments to issue laws, reduce sanctions, and prohibit the transit of specific streets.
\end{abstract}

Keywords: Deference, reparations, administrative justice.

Contents: 1. Introduction. 2. Deference. 3. Reparations. 4. Reparations in Colombia. 5. Reparations in Mexico. 6. Conclusions

\section{INTRODUCTION}

Usually analyses of deference consider courts' review of past agency action. Governments interpret in a specific manner a norm or regulation and the judge decides the lawfulness of that interpretation after the fact. However, judges analyze governments' future decisions as well, for example in granting reparations for human rights violations. Such

\footnotetext{
${ }^{1}$ Adriana Garcia Garcia is a professor at the Centro de Investigación y Docencia Económicas (CIDE) in Mexico and consultant at Open Society Justice Initiative. She holds a doctorate degree (JSD) from the University of Chicago Law School (2016), a juris doctor degree from the Autonomous Technological Institute of Mexico (Mexico), an LL.M. from the University of Chicago (2010) and a master in Law and Economics from the Complutense University (Spain). During her doctoral studies she was a visiting scholar at Columbia University (2012-2013). Her current research focuses on the study of reparations; state financial liability and administrative justice.
} 
decisions generally engage in an analysis of future actions that the government should perform in order to redeem victims and guarantee the violation will not recur. The underpinning principle of judicial deference is that a court should not attempt to second guess or substitute its judgment for the judgment of another decision maker, nor should it opine on the wisdom of a policy or law. The degree of deference will vary according to the levels of trust in the agency, the nature of the agency action, the enabling statute that provides the agency with power, and the specific issue in question. Through such considerations the court will determine how broad or narrow the scope of judicial review is in a certain case. With respect to human rights violations, a more deferential approach might let the government determine what measures it will take by way of reparations and prevention of recurrence, while a nondeferential approach would spell out such measures in detail.

International human rights standards oblige judges to issue reparations including measures of restitution, compensation, satisfaction, rehabilitation and non-repetition, but do not determine the appropriate level of deference, and international courts differ accordingly. While the European approach has tended towards a more deferential approach, the InterAmerican Court of Human Rights has been much less so. Examining cases in Colombia and Mexico issued during the past 10 years, in this paper I argue that the domestication of the InterAmerican human rights standards has led domestic courts to grant reparations in a less deferential manner over time. This trend is very clear when analyzing non-repetition measures granted in these countries which include attempts to oblige governments to issue laws, reduce sanctions, and prohibit the transit of specific streets.

In the first section I will address and explain the concept of deference as a characteristic of judges' attitudes towards governments. The second section will analyze the international standards of reparations, delving into the non-recurrence measures issued by the InterAmerican Court of Human Rights. The third section will be dedicated to the analysis of domestic decisions in Colombia and Mexico. The final section discusses the merits of the deferential approach vs. the non-deferential approach while granting reparations of human rights' violations in these countries.

\section{DEFERENCE}


As rightly noted by Anuradha Vaitheswaran and Thomas A. Mayes, a plain language definition of deference is respect or esteem for a superior ${ }^{2}$. For judicial deference, when a court is reviewing agency action, the judiciary "respects" the agency that is "superior" or elder. Hence, the underpinning principle of judicial deference is that a court should not attempt to second guess or substitute its judgment for the judgment of another decision maker, nor should it pass on the wisdom of a policy or law. ${ }^{3}$ Thus, deference consists of the method by which a court examines decisions made by the "bureaucratic state". 4

Three main justifications for the existence of deference are observed in the milestone case of Chevron v. Natural Resources Defense Council (1984): (i) agencies have greater political accountability than courts, (ii) agencies are often in a better position than the legislature to make difficult political choices, and (iii) agencies have greater expertise than courts and the legislature in administering often "technical and complex" regulatory schemes 5 .

Degrees of deference should be understood as degrees of respect toward agency action. If a court has more respect for the decisions of an agency, the deference used by the court to decide cases is greater. The three step analysis to establish the degree of deference include: to determine whether Congress has delegated authority to the agency to interpret the law; if it has, determine whether Congress has spoken directly about the particular issue; and if Congress has not spoken, assess whether the agency's interpretation is reasonable. These steps reflect the basic principles of judicial deference in the United States when assessing issues of law or mixed issues of law and fact. These principles have been outlined in three landmark cases, Chevron, Mead, and Skidmore. These cases have created a culture in which delegation in favor of the agency should be presumed where it is assumed (1) that the agency, rather than the reviewing court, is an expert on the statute in issue; (2) that resolving an ambiguity in a statute involves a policy judgment, which is more appropriately made by the agency than by a court; and (3)

\footnotetext{
${ }^{2}$ Anuradha Vaitheswaran \& Thomas A. Mayes, The Role of Deference in Judicial Review of Agency Action: A Comparison of Federal Law, Uniform State Acts, and the Iowa APA, 27 Journal of THE NATIONAL Association Of Administrative LAW JUDICIARY 402, 404 (2007).

${ }^{3}$ Daniel J. Solove, The Darkest Domain: Deference, Judicial Review, and the Bill of Rights, 84 Iowa Law ReVIEw 941, 943 (1999). The underlying principle of deference, as mentioned by Solove, is clearly reflected in Justice Holmes' famous dissent in Lochner in Lochner v. New York (1905): "I strongly believe that my agreement or disagreement has nothing to do with the right of a majority to embody their opinions in law."

${ }^{4}$ Daniel J. Solove, The Darkest Domain: Deference, Judicial Review, and the Bill of Rights, 84 Iowa Law ReVIEw 941, 943 (1999). The bureaucratic state is defined by Solove as "the web of interacting public and private institutions that regulate numerous facets of modern life."

${ }^{5}$ Melany D. Walker, Congressional Intent and Deference to Agency Interpretations of Regulations, 66 THE UNIVERSITY OF Chicago Law Review 1341, 1347 (1999).
} 
that the agency is authorized to make interpretations in a reasoned decision-making format (such as a legislative regulation) ${ }^{6}$.

\section{REPARATIONS}

Reparations are an indispensable element of fundamental international and national norms regarding human rights' violations cases. At the international level, every judgement finding a violation of human rights grants reparations to the victim. According to international norms and standards, reparations must be adequate, effective and comprehensive. ${ }^{7}$

Comprehensive reparation "means the re-establishment of the previous situation and the removal of the results which the violation produced"; 8 and considers, in addition to monetary compensation, the granting of other types of means of reparation such as restitution, rehabilitation, satisfaction and guarantees of non-repetition. ${ }^{9}$

Among these measures the one that covers the greater scope of government's powers is non-repetition measures. Non repetition measures may include issuing effective, clear instructions to public officials, strengthening the independence of the judiciary; establishing systems for regular and independent monitoring of all places of detention; providing, on a priority and continued basis, training for law enforcement officials as well as military and security forces on human rights law; reviewing and reforming laws; ensuring the availability of temporary services for individuals or groups of individuals, such as shelters for victims of gender-related or other torture or ill-treatment. ${ }^{10}$ While granting such types of measures has been applauded by victims' advocates it is clear that international judges attitudes towards governments cannot be described as deferential.

Reparations at the domestic level are also important elements of legal systems. At least 60 federal constitutions in the world spell out the right of victims of human rights abuses to obtain reparations. Among these, countries transitioning from an authoritative regime to a democratic one have increased the importance of the issue as reparations are seen as integral

\footnotetext{
${ }^{6}$ Chevron USA Inc. v. Natural Res. Def. Council Inc., 467 U.S. 837 (1984), 1175.

${ }^{7}$ UN Committee Against Torture (CAT), General comment no. 3, 2012: Convention against Torture and Other Cruel, Inhuman or Degrading Treatment or Punishment: implementation of article 14 by States parties (Dec. 13, 2012) paragraphs 2 and 6.

${ }^{8}$ Case of González et al. (“Cotton Field”) v. Mexico, IACtHR, Judgement of November 16, 2009, para. 450.

${ }^{9}$ Case of the Plan de Sánchez Massacre v. Guatemala, IACtHR, Judgement of April 29, 2004; Case of Rodríguez Vera et al. (The Disappeared from the Palace of Justice) v. Colombia, IACtHR, Judgement of November 14, 2014, Series C No. 287 , para. 543; Case of Herrera Espinoza et al. v. Ecuador, IACtHR, Judgement of September 1, 2016, Series C No. 316 , para. 214. ${ }^{10}$ UN Committee Against Torture (CAT), General comment no. 3, 2012: Convention against Torture and Other Cruel, Inhuman or Degrading Treatment or Punishment: implementation of article 14 by States parties (Dec. 13, 2012) paragraph 18.
} 
part of processes to address violations of the past. In recent years and as a result of the international influence, some countries have incorporated international standards regarding reparations into their own legal systems. As a result of the domestication of such standards, domestic judges have become less deferential towards government agencies when granting reparations. In this paper I will analyze two case studies: Colombia and Mexico. Each of these countries has issued interesting decisions obliging governments to issue laws, enact broad policies or void public policies.

\section{REPARATions in COLOMBia}

At a national level it can be observed that judges also use measures of non-repetition as part of reparations. Judges in Colombia, which has struggled with a long and brutal civil conflict and battles with drug gangs, developed sophisticated jurisprudence on reparations for abuses committed by state forces, including not only compensation but also rehabilitation to victims and the enactment of laws as non-recurrence measures.

For example, when the Constitutional Court of Colombia finds that various cases show systematic and continual violations of human rights, it issues a decision called the Unconstitutional State of Affairs where it underlines the structural causes of such violations and requires the government to take effective measures to remove the causes. ${ }^{11}$ The court has issued this type of decision in cases of displaced women and overcrowding in prisons. ${ }^{12}$

Similarly, the Constitutional Court of Colombia has established that: "The guarantee of non-repetition is composed of all the actions aimed at preventing behavior from re-occurring which impacted on the rights of the victims and which must be appropriate to the nature and magnitude of the offence. The guarantee of non-repetition is directly related to the obligation of the State to prevent gross violations of human rights; this includes the adoption of measures of a legal, political, administrative and cultural nature that promote safeguarding rights. In particular, the following contents of this obligation have been identified: (i) recognize the rights at an international level and offer guarantees of equality; (ii) draw up and implement strategies and policies of comprehensive prevention; (iii) implement programs of education and dissemination aimed at eliminating patterns of violence and infringement of rights and inform people of rights, mechanisms of protection and the consequences of their infringement; (iv) introduce programs and promote practices that allow an effective response to complaints of

\footnotetext{
${ }^{11}$ Judgement T-025/2004, Constitutional Court of Colombia, of January 22, 2004.

12 Judgement T-388/2013, Constitutional Court of Colombia, of June 28, 2013.
} 
human rights violations as well as strengthen institutions with functions in that field; (v) assign sufficient resources to support prevention efforts; (vi) adopt measures to eradicate risk factors; this includes devising and implementing instruments to facilitate the identification and notification of factors and events that pose the risk of violation; (vii) take specific prevention measures in cases where a group of people is found to be at the risk of their rights being violated."13

In turn, the Council of State of Colombia has played an active role in granting measures of non-repetition. In its jurisprudence it has reiterated that: "In order to specify the preventive role which jurisprudence must have on administrative disputes... in cases of gross violations of human rights (...) it is of great importance for the Council of State to highlight, in cases such as the present one, the inappropriate behavior committed by state agents, with the aim of setting a precedent which obliges the public administration to pull out by the root this type of behavior and for the case to receive due reparation which would make the recurrent recourse of citizens to international organizations unnecessary." 14

\section{REPARATIONS IN MeXico}

Non- repetition guarantees are perhaps one of the most explored concepts, in terms of reparations, by the Supreme Court of Mexico. Article 27 of the Mexican General Law on Victims defines non-repetition guarantees as measures to ensure that the acts resulting in a human rights violation will not happen again. The Court, whenever addressing a human rights violation issue and the reparations that must emanate from it, has been clear about the necessity of implementing public policies that would guarantee an environment respectful of human rights, through institutional, social and cultural change. For example:

In Amparo 476/2014, the Supreme Court established that non-monetary reparations, also known as moral reparations, are classified as: a) restitution and rehabilitation, b) satisfaction, and c) guarantees of non-repetition. Guarantees of non-repetition are intended to ensure that the State's harmful actions are never to be repeated and they consist on public policies aimed to influence social, legal and political institutions ${ }^{15}$

In Amparo 476/2014 the Supreme Court established the State's obligation to investigate, punish and remedy human rights violations entails the execution of everything

\footnotetext{
${ }^{13}$ Judgement T-418/15, Constitutional Court of Colombia, of July 3, 2015.

${ }^{14}$ Case of Sapuyes Argote et al., Section III, Subsection B, Council of State of Colombia, Judgement of April 30, 2014, Loc. 28075.

${ }^{15} \mathrm{Ibid}$.
} 
necessary to achieve its restoration. Therefore, human rights immediate observance can be demanded through comprehensive reparations or it could result in progressive actions. In the latter sense, the solution adopted by the State should serve not only to particular interest but also to the purpose of restructuring political and social environment that is respectful of human rights. In other words, reparations are about thinking about a particular case but also to promote actions that can serve as guidelines for future governmental activities. ${ }^{16}$

As established by the Supreme Court, in Mexico, lower and administrative courts have notably ordered state institutions to publicly acknowledge their responsibility for human rights violations - such as the public apology delivered by the federal prosecutor in February, 2017, to three indigenous women who had spent three years in prison on fabricated charges. ${ }^{17}$ Mexico's eventual decision in December, 2018, to create a commission of inquiry into the disappearance of 43 students in the infamous 2014 Ayotzinapa case was also informed by a court order. Other measures ordered in Mexico have included requiring city authorities to list streets deemed unsafe for unaccompanied women, and requiring the publication by the executive branch of Gender Violence Alerts in the State of Mexico in 2018.

\section{Conclusions}

Beyond the restorative function of reparations, if properly designed, reparations can generate the correct incentives to minimize illegal actions of government in the future. Measures of reparations impose costs on government actions. In fact, recent reviews of the deterrence literature from domestic legal systems conclude that there is much firmer evidence for a substantial deterrent effect than there was two decades ago. ${ }^{18}$

Reparations are undoubtedly related to the issue of preventing impunity. ${ }^{19}$ Therefore, judges should consider not only the specific circumstances of the individual case, but also the deterrent effects of the decision for future violations. In this regard, the analysis of reparations functions is concerned not only with the individual case but also with how reparations affect

\footnotetext{
${ }^{16} \mathrm{Ibid}$.

${ }^{17}$ Adriana Garcia \& Mercedes Melon, How Mexican Human Rights Lawyers Found a New Route to Accountability, OPEN SOCIETY FoundATIONS (Feb. 21, 2017).

${ }^{18}$ Daniel S. Nagin, Criminal Deterrence Research at the Outset of the Twenty-First Century, in CRIME AND JusTICE: A REVIEW of RESEARCH 1-42 (M. Tonry ed., 1998).

${ }^{19}$ Theo Van Boven, The United Nations Basic Principles and Guidelines on the Right to a Remedy and Reparation for Victims of Gross Violations of International Human Rights Law and Serious Violations of International Humanitarian Law, UNITED NATIONS AUdiovisuAl LibRARY OF INTERNATIONAL LAW, 2010.
} 
other actors' future behavior and judges cannot analyze the latter without engaging in a nondeferential approach. ${ }^{20}$

While the deference literature focuses on the benefits of allowing expert agencies to issue decisions and specific measures, the human Rights' debate on reparations makes clear that when analyzing Human Rights violations issues it is more important to ensure the respect to Human Rights rather than the respect to agencies' expertise.

\section{REFERENCE LIST}

Adriana Garcia \& Dirk Zavala Rubach, The Judicial Power and the Human Rights' Amendment. A Game Theory Analysis", in The Constitutional AMENDMENT On Human RIGHTS: THE COST OF ITS IMPLEMENTATION 23-48 (2014).

Adriana Garcia \& Mercedes Melon, How Mexican Human Rights Lawyers Found a New Route to Accountability, OPEN SOCIETY FOUNDATIONS (Feb. 21, 2017), https://www.opensocietyfoundations.org/voices/how-mexican-human-rights-lawyers-foundnew-route-accountability

Anuradha Vaitheswaran \& Thomas A. Mayes. The Role of Deference in Judicial Review of Agency Action: A Comparison of Federal Law, Uniform State Acts, and the Iowa APA, 27 Journal of the NATIONAL Association OF ADMINISTRATIVE LAW JUdiCIARY 402-46 (2007).

Case of González et al. ("Cotton Field") v. Mexico, IACtHR, Judgement of November 16, 2009.

Case of Herrera Espinoza et al. v. Ecuador, IACtHR, Judgement of September 1, 2016, Series C No. 316, para. 214.

Case of Rodríguez Vera et al. (The Disappeared from the Palace of Justice) v. Colombia, IACtHR, Judgement of November 14, 2014, Series C No. 287.

Case of Sapuyes Argote et al., Section III, Subsection B, Council of State of Colombia, Judgement of April 30, 2014, Loc. 28075.

Case of the Plan de Sánchez Massacre v. Guatemala, IACtHR, Judgement of April 29, 2004.

Chevron USA Inc. v. Natural Res. Def. Council Inc., 467 U.S. 837 (1984).

Daniel J. Solove, The Darkest Domain: Deference, Judicial Review, and the Bill of Rights, 84 IOWA LAW REVIEW 941-1023 (1999).

Daniel S. Nagin, Criminal Deterrence Research at the Outset of the Twenty-First Century, in 21 CRime AND Justice: A REVIEW OF RESEARCH 1-42 (M. Tonry ed., 1998).

Judgement T-025/2004, Constitutional Court of Colombia, of January 22, 2004.

Judgement T-388/2013, Constitutional Court of Colombia, of June 28, 2013.

Judgement T-418/15, Constitutional Court of Colombia, of July 3, 2015.

${ }^{20}$ See Adriana Garcia \& Dirk Zavala Rubach, The Judicial Power and the Human Rights' Amendment. A Game Theory Analysis, in The Constitutional Amendment on Human Rights: The Cost of its Implementation 23-48 (2014). 
Melany D. Walker, Congressional Intent and Deference to Agency Interpretations of Regulations, 66 THE UnIVERSITY OF CHICAGO LAW REVIEW 1341-71 (1999).

Theo Van Boven, The United Nations Basic Principles and Guidelines on the Right to a Remedy and Reparation for Victims of Gross Violations of International Human Rights Law and Serious Violations of International Humanitarian Law, UNITED NATIONS AUDIOVISUAL LIBRARY OF INTERNATIONAL LAW (2010).

UN Committee Against Torture (CAT), General comment no. 3, 2012: Convention against Torture and Other Cruel, Inhuman or Degrading Treatment or Punishment: implementation of article 14 by States parties (Dec. 12, 2012). 